\title{
Interleukin-6 primarily produced by non- hematopoietic cells mediates the lipopolysaccharide-induced febrile response
}

Namik Hamzik, Yan-juan Tang, Anna Eskilsson, Unn Örtegren Kugelberg, Johan Ruud, JanIngvar Jönsson, Anders Blomqvist and Camilla Nilsberth

\section{Linköping University Post Print}

\section{Tweet}

N.B.: When citing this work, cite the original article.

Original Publication:

Namik Hamzik, Yan-juan Tang, Anna Eskilsson, Unn Örtegren Kugelberg, Johan Ruud, JanIngvar Jönsson, Anders Blomqvist and Camilla Nilsberth, Interleukin-6 primarily produced by non-hematopoietic cells mediates the lipopolysaccharide-induced febrile response, 2013, Brain, behavior, and immunity, (33), 123-130.

http://dx.doi.org/10.1016/j.bbi.2013.06.006

Copyright: Elsevier http://www.elsevier.com/

Postprint available at: Linköping University Electronic Press http://urn.kb.se/resolve?urn=urn:nbn:se:liu:diva-99401 
Interleukin-6 primarily produced by non-hematopoietic cells mediates the lipopolysaccharide-induced febrile response

Namik Hamzic, Yanjuan Tang, Anna Eskilsson, Unn Kugelberg, Johan Ruud, Jan-Ingvar Jönsson, Anders Blomqvist, Camilla Nilsberth*

Linköping University, Faculty of Health Sciences, Department of Clinical and Experimental Medicine, Division of Cell Biology, SE-581 85 Linköping, Sweden.

*Corresponding author. Address: Linköping University, Faculty of Health Sciences,

Department of Clinical and Experimental Medicine, Division of Cell Biology, SE-581 85

Linköping, Sweden. Phone: +46 10103 7469; E-mail: camilla.nilsberth@liu.se

Key words: Interleukin-6, hematopoietic cells, bone marrow transplantation, fever

Disclosure statement: The authors have nothing to disclose 


\begin{abstract}
Interleukin-6 (IL-6) is critical for the lipopolysaccharide (LPS)-induced febrile response.

However, the exact source(s) of IL-6 involved in regulating the LPS-elicited fever is still to be identified. One known source of IL-6 is hematopoietic cells, such as monocytes. To clarify the contribution of hematopoietically derived IL-6 to fever, we created chimeric mice expressing IL-6 selectively either in cells of hematopoietic or, conversely, in cells of non-hematopoietic origin. This was performed by extinguishing hematopoietic cells in wild-type (WT) or IL-6 knockout (IL-6 KO) mice by whole-body irradiation and transplanting them with new stem cells. Mice on a WT background but lacking IL-6 in hematopoietic cells displayed normal fever to LPS and were found to have similar levels of IL-6 protein in the cerebrospinal fluid (CSF) and in plasma and of IL-6 mRNA in the brain as WT mice. In contrast, mice on an IL-6 KO background, but with intact IL-6 production in cells of hematopoietic origin, only showed a minor elevation of the body temperature after peripheral LPS injection. While they displayed significantly elevated levels of IL-6 both in plasma and CSF compared with control mice, the increase was modest compared with that seen in LPS injected mice on a WT background, the latter being approximately 20 times larger in magnitude. These results suggest that IL-6 of non-hematopoietic origin is the main source of IL-6 in LPS-induced fever, and that IL-6 produced by hematopoietic cells only plays a minor role.
\end{abstract}




\section{Introduction}

Fever is an adaptive defense that is necessary for the protection and survival of the host in the presence of pathogenic agents (Kluger et al., 1975). The signaling pathways regulating fever are complex and still remain unclear. It is however generally accepted that prostaglandin $\mathrm{E}_{2}\left(\mathrm{PGE}_{2}\right)$, acting on prostaglandin $\mathrm{E}$ receptor type $3\left(\mathrm{EP}_{3}\right)$ expressing neurons in the preoptic area of the hypothalamus, is the principal mediator of fever (Engblom et al., 2003; Lazarus et al., 2007). In experimental animals, lipopolysaccharide (LPS), a component of the cell wall envelope of Gram-negative bacteria, is commonly used to provoke a febrile response (Oka et al., 2003; Romanovsky et al., 1998; Rudaya et al., 2005). A large part of the LPS-elicited production of $\mathrm{PGE}_{2}$ and concomitant fever response is thought to involve cytokines, such as

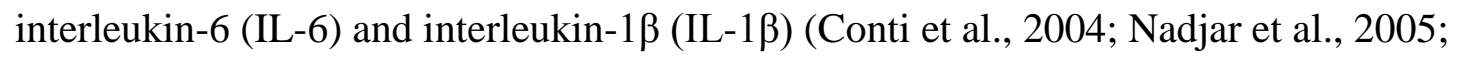
Rummel et al., 2011).

IL-6 is a critical proinflammatory cytokine for the febrile response, because neither IL-6 knock-out (IL-6 KO) mice, nor animals treated with IL-6 antiserum develop fever upon peripheral immune stimulation (Cartmell et al., 2000; Chai et al., 1996; Kozak et al., 1998). However, depending on species, IL-6 per se has been reported to induce no or only weak to moderate fever (Blatteis, 1990; Cartmell et al., 2000; Dinarello et al., 1991; Harre et al., 2002; Nilsberth et al., 2009a; Rummel et al., 2006; Sakata et al., 1991; Wang et al., 1997). Several explanations for these contradictory observations have been proposed. For example, it has been suggested that IL-6 needs to reach a threshold level to activate the transcription factor STAT3 and initiate fever (Rummel et al., 2004). Another hypothesis is that IL-6 and IL-1 $\beta$ act in a synergistic way, based on the finding that IL-6 induces fever if administered together with a subfebrile dose of IL-1 $\beta$ (Cartmell et al., 2000; Harden et al., 2008). Thus, although the presence of IL-6 has been shown to be necessary for fever, its role in the regulation of the febrile response is not clear. 
IL-6 is a pleiotropic cytokine with widespread expression. IL-6 is synthesized and secreted by monocytes/macrophages (Bauer et al., 1988; Callery et al., 1992; May et al., 1988; Northoff et al., 1987), fibroblasts (Helfgott et al., 1987; May et al., 1988), brain endothelial cells (Kakumu et al., 1992; Reyes et al., 1999; Verma et al., 2006), muscle cells (Andreasen et al., 2011), and hepatocytes (Panesar et al., 1999; Saad et al., 1995) following challenge with bacterial endotoxin. IL-6 has also been shown to be produced by astrocytes (Benveniste et al., 1990; Beurel and Jope, 2009), microglial cells (Sawada et al., 1992; Woodroofe et al., 1991), adipocytes (Flower et al., 2003), and neurons (Ringheim et al., 1995; Vallieres and Rivest, 1997) following different stimuli. IL-6 is thus synthesized by several different cells, however it has been difficult to determine the contribution of a specific cell type in vivo. For instance, the role of IL-6 produced by hematopoietic cells versus that produced by cells of non-hematopoietic lineage in LPS-induced fever remains to be clarified.

Here we examined the role of IL-6 derived from hematopoietic and non-hematopoeitic cells, respectively, in LPS-induced fever in mice chimeric for IL-6, meaning that they expressed IL-6 selectively either in cells of hematopoietic or non-hematopoietic origin. Chimeric mice were produced by exposing IL-6 KO and wild-type mice (WT) to whole body irradiation followed by transplantation with bone marrow cells from the opposite genotype. Thus, two chimeras were generated: WT mice with KO bone marrow (expressing IL-6 derived from non-hematopoietic cells) and KO mice with WT bone marrow (expressing IL-6 from cells of hematopoietic origin). This experimental set-up made it possible to distinguish between the febrile response mediated by IL- 6 produced by non-hematopoietic cells and IL- 6 produced by hematopoietically derived cells. The results show that IL-6 produced by cells of non-hematopoietic origin primarily is responsible for eliciting the febrile response following peripheral challenge with LPS, whereas IL-6 from hematopoietically derived cells only plays a minor but significant and time dependent role in the LPS-induced fever. 


\section{Materials and Methods}

\subsection{Animals}

C57 BL/6 mice deficient in IL-6 (IL-6 KO) and their WT littermates were used (Jackson Laboratory, Bar Harbor, ME). For transplantation experiments (donor bone marrow), the IL-6 $\mathrm{KO}$ mice were crossed with a C57BL/6 strain expressing green fluorescent protein (GFP) [C57BL/6-Tg(CAG-EGFP)C14-Y01-FM131Osb; kindly provided by Dr. Masaru Okabe, Osaka University, Japan (Okabe et al., 1997)] and the resulting IL-6 heterozygous mice were then crossed to generate GFP ${ }^{+} \mathrm{IL}-6 \mathrm{KO}$ and $\mathrm{GFP}^{+} \mathrm{WT}$ mice, used as bone marrow donors. All mice were housed one to three per cage in a pathogen-free facility at an ambient temperature of $20-21^{\circ} \mathrm{C}$ and with humidity between $30-50 \%$, with food and water available ad libitum on a 12:12-h light-dark cycle (lights on at $07.00 \mathrm{~h}$ ). The donor mice were $8-10$ weeks old at the time of experiment. The mice receiving bone marrow transplantation were $2-5$ months old at the time of irradiation and transplantation and 7-10 months old when sacrificed for experiments. Body weight $( \pm \mathrm{SD})$ at the time of the experiment was for $\mathrm{WT} \rightarrow \mathrm{WT}: 32.4 \mathrm{~g} \pm$ 5.1; for $\mathrm{WT} \rightarrow \mathrm{KO}: 30.6 \mathrm{~g} \pm 3.8$; for $\mathrm{KO} \rightarrow \mathrm{WT}: 31.3 \mathrm{~g} \pm 5.9$; and for $\mathrm{KO} \rightarrow \mathrm{KO}: 32.4 \mathrm{~g} \pm 5.9$ [there were no significant differences between the groups, as analyzed by a one-way ANOVA $(P=0.46)]$. All experimental procedures were approved by the Animal Care and Use Committee at the Linköping University.

\subsection{Irradiation and bone marrow transplantation}

WT and IL-6 KO littermates of mixed gender were used. Groups were balanced to contain about equal proportions of male and female mice. They were irradiated in a cage with two opposed fields, using a linear accelerator (Varian Clinac 600C) with a 6 MV photon spectra to a total absorbed dose in water of $9 \mathrm{~Gy}$, single fraction. The irradiation procedure 
followed the same experimental set-up as described earlier (Eliasson et al., 2010). Mice were injected intravenously within 6-18 hours post-irradiation with $2 \times 10^{6}$ freshly prepared $\mathrm{GFP}^{+} \mathrm{CD} 45^{+}$bone marrow cells from either IL-6 KO or WT mice, in a total volume of $0.2 \mathrm{ml}$. Cells to be transplanted were collected from femurs and tibias after crushing the bones in icecold Dulbecco`s phosphate buffered saline (PBS) (PAA Laboratories, Pasching, Austria) supplemented with $5 \%$ fetal calf serum (FCS) using a mortar and pestle. The bone marrow mixture was repeatedly passed through a 14 gauge needle and the resulting cell suspension, also containing small bone fragments, was transferred to a Falcon tube in which the bone fragments were allowed to sediment. The medium was carefully decanted and centrifuged. The obtained pellet was dissolved in ice-cold Dulbecco's PBS supplemented with $5 \%$ FCS and subsequently filtered through a $70 \mu$ m nylon mesh (BD Biosciences). Cells were then transferred to ice-cold Dulbecco's PBS supplemented with $5 \%$ FCS containing anti-mouse CD45 magnetic microbeads (1:10; Miltenyi Biotec, Bergisch Gladbach, Germany) and incubated for $20 \mathrm{~min}$ at $4^{\circ} \mathrm{C}$.

$\mathrm{CD} 45^{+}$cells were enriched according to the manufacturer's instructions using the quadroMACS separation system with LS columns (Miltenyi Biotec). After an additional filtration, the cells were counted in a Bürker chamber and diluted to a final concentration of $10^{7}$ cells $/ \mathrm{ml}$ in Dulbecco's PBS. Aliquots of $0.2 \mathrm{ml}$ of the final cell solution, one for each recipient mouse, were kept on ice until the moment of injection. After the injection, mice were immediately transferred to an isolated room with autoclaved cages (1-3 mice per cage) and received sterilized food and autoclaved water. During the first 3 weeks post transplantation, the water was supplemented with an antibiotic (Ciprofloxacin, $0.1 \mathrm{mg} / \mathrm{ml}$; BMM Pharma, Stockholm, Sweden). 


\subsection{Flow Cytometry}

Peripheral blood was collected by lateral tail vein bleeding into heparin treated tubes (5000 IE/ml; Leo Pharma, Malmö, Sweden) 5 months post transplantation. Equal volumes of PBS supplemented with $1 \%$ FCS and $2 \%$ Dextran (Sigma, St. Louis, MO) were added to each sample followed by incubation at $37^{\circ} \mathrm{C}$ for $20 \mathrm{~min}$. The upper phase was transferred to a new tube and centrifuged at 3,000 rpm for $4 \mathrm{~min}$. The supernatant was carefully decanted, and the pellet dissolved with $0.2 \mathrm{ml}$ ammonium chloride (StemCell Technologies, Grenoble, France) and incubated for 2 min to lyse residual erythrocytes. The cells were resuspended in PBS supplemented with $1 \%$ FCS and analyzed for GFP expression by flow cytometry on a FACSCanto device (BD Biosciences, Franklin Lakes, NJ) using FACSDiva software (BD Biosciences). Non-transplanted WT C57BL/6 mice and $\mathrm{GFP}^{+}$mice were used as controls.

\subsection{Immunohistochemistry}

Mice were asphyxiated with $\mathrm{CO}_{2}$ and perfused with $0.9 \%$ saline, followed by $4 \%$ icecold paraformaldehyde in phosphate buffer $(0.1 \mathrm{M}, \mathrm{pH}$ 7.4). The brains were dissected and post-fixed for $3 \mathrm{~h}$ in the same fixative at $4^{\circ} \mathrm{C}$ and subsequently transferred to ice-cold PBS containing $30 \%$ sucrose overnight. Sections were cut transversely at $30 \mu \mathrm{m}$ on a freezing microtome, collected in sterile bins containing cold cryoprotectant ( $0.05 \mathrm{M}$ sodium phosphate buffer, $30 \%$ ethylene glycol, $20 \%$ glycerol), and stored at $-20^{\circ} \mathrm{C}$ until use. For antibody detection under bright field illumination, the brain sections were stained for GFP immunoreactivity using a chicken anti-GFP antibody (1:1000; Abcam, Cambridge, UK) overnight at room temperature, and, following rinses with PBS, incubated with biotinylated goat anti-chicken antibody (1:1000; Vector Laboratories, Peterborough, UK) and avidinbiotin complex (1:1000; Vector) for $2 \mathrm{~h}$ each at room temperature. Color was developed using 3,3'-diaminobenzidine tetrahydrochloride (Sigma) containing $0.01 \% \mathrm{H}_{2} \mathrm{O}_{2}$ and $2.25 \%$ nickel 
ammonium sulfate in $0.1 \mathrm{M}$ sodium-acetate buffer $(\mathrm{pH}$ 6.0) for $3 \mathrm{~min}$. For dual staining, the brain sections were incubated at room temperature overnight in a mixture of chicken anti-GFP antibody (1:10 000; Abcam) and either rat anti-mouse CD206 antibody (1.500; Serotec, Raleigh, North Carolina), a marker for perivascular macrophages (Galea et al., 2005), or sheep anti-von Willebrand factor (vWF) antibody (1:1000; Abcam), used here as marker for endothelial cells (Jaffe et al., 1974) (Sporn et al., 1986). Secondary antibodies were DyLight Fluor 488 donkey anti-chicken IgG (1:500; Invitrogen, Carlsbad, CA), and either Alexa Fluor 568 donkey anti-sheep IgG (1:500; Invitrogen) or Alexa Fluor 568 goat anti-rat IgG (1:500; Invitrogen). Dual-labeled brain sections were analyzed on a Zeiss Axio Observer Z1 fluorescence microscope connected to a Zeiss LSM 700 confocal unit with 405,488, 555 and $639 \mathrm{~nm}$ diode lasers.

\subsection{Plasma and cerebrospinal fluid}

The mice were injected i.p. either with LPS or saline and sacrificed $3 \mathrm{~h}$ later using asphyxiation with $\mathrm{CO}_{2}$. Blood was drawn from the right atrium using a $1 \mathrm{ml}$ syringe and a 23 gauge needle, transferred to EDTA-coated tubes (Sarstedt, Landskrona, Sweden) and centrifuged at $7,000 \mathrm{~g}$ for $7 \mathrm{~min}$ at $4{ }^{\circ} \mathrm{C}$. The plasma was frozen immediately on dry ice and kept at $-70^{\circ} \mathrm{C}$, until used. Samples with hemolysis were discarded. After the withdrawal of blood from the heart, the mouse was fixed in a stereotactic device with the head flexed anteriorly. Neck muscles were divided in the midline to expose the atlanto-occipital membrane. Cerebrospinal fluid (CSF; $1-3 \mu \mathrm{l})$ was collected from the cisterna magna using a Hamilton syringe, and immediately frozen on dry ice. Samples that were contaminated with blood were discarded. The entire procedure after the mice had been asphyxiated took less than

10 min. The concentration of IL-6 in CSF and plasma was determined using a Bio-Plex Pro ${ }^{\mathrm{TM}}$ 
Mouse Cytokine Assay Kit according to the manufacturer's instructions (Bio-Rad, Hercules, CA).

\subsection{Real Time RT-PCR}

The mice were asphyxiated with $\mathrm{CO}_{2} 3 \mathrm{~h}$ after i.p. injection of LPS and perfused transcardially with an ice-cold $0.9 \%$ saline solution. The brains were dissected and immediately frozen on dry ice and kept at $-20^{\circ} \mathrm{C}$, until processed. Total RNA from the cerebral cortex was extracted using RNeasy Lipid Tissue Kit (Qiagen, Hilden, Germany) according to the manufacturer's instructions, including deoxyribonuclease treatment with ribonuclease-free deoxyribonuclease set (Qiagen). The concentrations and purity of extracted RNA were measured using the NanoDrop ND-1000 Spectrophotometer, demonstrating RNA with high purity with the $260 / 280$ absorbance ratio between 2.1 to 2.2 and concentrations between $73-773 \mathrm{ng} / \mu \mathrm{l}$ (NanoDrop, Wilmington, DE).

A total of 500 ng of RNA was reversely transcribed to cDNA by random hexamer priming using PrimeScript first-strand cDNA synthesis kit (TaKaRa Bio, Shiga, Japan). Real time RT-PCR was performed on an Applied Biosystems 7900 Fast Real-Time PCR System using Fast SYBR ${ }^{\circledR}$ Green Master Mix, according to the manufacturer's instructions. A total of $10 \mathrm{ng}$ template was used. Primers for IL-6 (Cybergene, Stockholm, Sweden) and hydroxymethylbilane synthase (HMBS) (Sigma), used as a housekeeping gene for sample normalization, were applied to a final concentration of $10 \mu \mathrm{M}$. The oligonucleotide sequences for primer pairs used were: 5'-TTC CAT CCA GTT GCC TTC TTG G-3` (IL-6 forward), 5’TTC TCA TTT CCA CGA TTT CCC AG-3` (IL-6 reverse) (protocol obtained from The Jackson Laboratory designed for the Il6tm1 Kopf/J mouse, http://jaxmice.jax.org/strain/007078.html), 5`CGC ATC TGG AGT TCA GGA GTA-3` (HMBS forward), and 5 -CCA GGA TGA TGG CAC TGA-3` (HMBS reverse). The Ct 
values were analyzed using the $2^{-\Delta \Delta \mathrm{Ct}}$ method. Obtained values for $\mathrm{KO} \rightarrow \mathrm{KO}$ and $\mathrm{WT} \rightarrow \mathrm{KO}$ mice irrespective of treatment as well as for non-template controls were around 31 cycles. Analysis of melting curves suggested the presence of primer dimerization resulting in unspecific signal. Therefore a cut-off was set to 31 cycles. Three different TaqMan probes were tested targeting different regions of the IL-6 gene but resulting in a similar phenomenon [Mm00446190_m1, (Herrero et al., 2010); Mm01210733_m1, (Semple et al., 2010); Mm00446191_m1, (Roedder et al., 2013)].

\subsection{Telemetric recordings and injections}

A transmitter (model TA10TA-F10; Data Science International, St. Paul, MN) that records core temperature was inserted into the mouse peritoneal cavity under brief anesthesia with 1 $\%$ isoflurane (Abbot Scandinavia, Solna, Sweden). Before suturing, Temgesic (RB Pharmaceuticals, Slough, Berkshire, UK; $100 \mu \mathrm{g} / \mathrm{kg}$ ) was added into the wound as analgesic treatment. Immediately after surgery, the mice were transferred to a room in which the ambient temperature was set to $29-30^{\circ} \mathrm{C}$. The mice were allowed to recover for at least one week before any further procedures were performed. The body temperature was monitored in each mouse during $10 \mathrm{sec}$ every $2 \mathrm{~min}$ beginning at least 1 day before injection, to assure that they displayed normal body temperature with normal circadian temperature variation. The mice were immune challenged with a single i.p. injection of LPS from Escherichia coli (Sigma; 0111:B4) at a dose of $120 \mu \mathrm{g} / \mathrm{kg}$ body weight. LPS was diluted in $100 \mu \mathrm{l}$ saline and injected i.p. at around 09.00 h. Control animals were injected i.p. with the vehicle only.

\subsection{Statistics}

Temperature data were analyzed with two-way ANOVA and data on IL-6 in plasma, CSF and cerebral cortex were analyzed with one-way ANOVA, both followed by Bonferroni 
post hoc test with correction for multiple comparisons. $P<0.05$ was considered statistically significant. Data are expressed as mean \pm SEM. In some sets of data analysis (the expression of IL-6 mRNA in the cerebral cortex, and the concentration of IL-6 in the CSF), the chimeric mice injected with saline were pooled into one group.

\section{Results}

\subsection{Irradiation and bone marrow transplantation resulted in extensive replacement of hematopoietic cells in both blood and brain}

Mice chimeric for IL-6 were created by exposing IL-6 KO mice and their WT littermates to whole body $\gamma$-irradiation ( $9 \mathrm{~Gy}$ ), a treatment that ablates the bone marrow stem cells. The mice were thereafter transplanted with $\mathrm{CD}_{4} 5^{+}$enriched $\mathrm{GFP}^{+}$bone marrow donor cells from the opposing genotype (WT or KO, respectively). Hence, after the bone marrows of recipients were repopulated two different chimeras were obtained: IL-6 KO mice with WT hematopoietic cells $(\mathrm{WT} \rightarrow \mathrm{KO})$ and WT mice with IL-6 KO hematopoietic cells $(\mathrm{KO} \rightarrow \mathrm{WT})$. WT mice transplanted with WT bone marrow $(\mathrm{WT} \rightarrow \mathrm{WT})$ and $\mathrm{KO}$ mice transplanted with KO bone marrow $(\mathrm{KO} \rightarrow \mathrm{KO})$ were also generated and served as controls. The chimeric mice were allowed to recover during five months after transplantation in order to obtain as effective reconstitution as possible of the hematopoietic cells, but at the same time avoiding that the mice became senescent. The level of reconstitution was examined both in peripheral blood and in the brain. Samples of peripheral blood were collected 7-10 days before immune challenge with LPS. The proportion of $\mathrm{GFP}^{+}$cells among the white blood cells in the peripheral blood, determined by flow cytometry, revealed that approximately $87 \% \pm 7 \%$ of blood leukocytes were derived from the transplanted bone marrow cells (Fig. 1). Accordingly, the irradiation and transplantation procedure generated highly selective and extensive replacement of native hematopoietic cells with transplanted cells. 


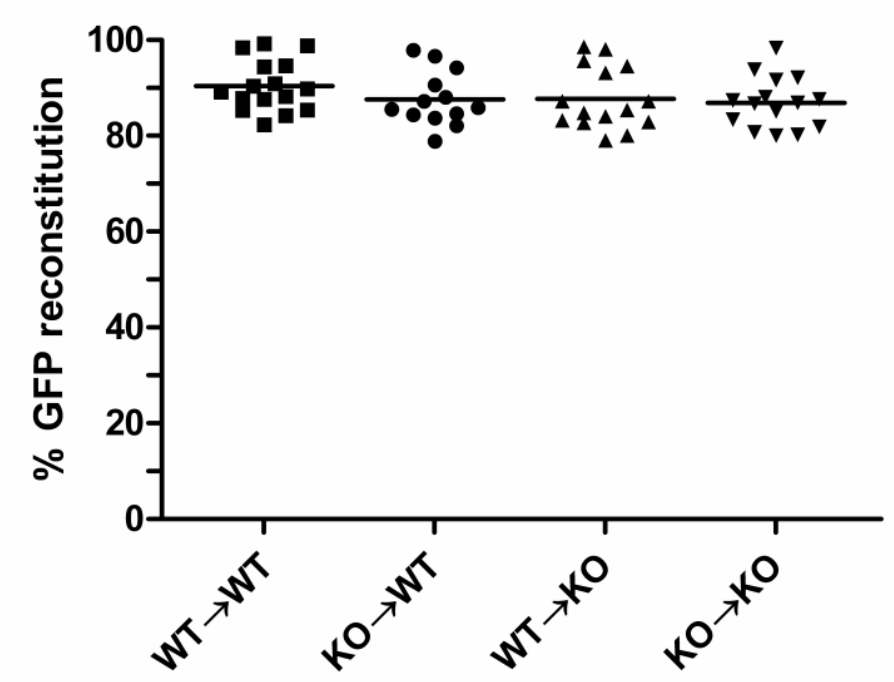

Fig. 1. GFP+ cell reconstitution in peripheral blood following irradiation and bone marrow transplantation

Mice with deletion of IL-6 (IL-6 KO) and their wild-type (WT) counterparts were exposed to whole body irradiation destroying the bone marrow stem cells and subsequently repopulated with CD45 enriched bone marrow cells $\left(2 \times 10^{6}\right.$ in a volume of $200 \mu \mathrm{L}$ per mouse) from donor mice (either GFP ${ }^{+} \mathrm{WT}_{\text {or }} \mathrm{GFP} \mathrm{KO}^{+}$mice) via an intravenous tail injection. The reconstitution of $\mathrm{GFP}^{+}$cells in peripheral blood of recipient mice was analyzed by flow cytometry five months after transplantation. Percentages of GFP labeled white blood cells in recipient mice are shown. WT $\rightarrow$ WT: WT mice transplanted with WT bone marrow; KO $\rightarrow$ WT: WT mice transplanted with KO bone marrow; WT $\rightarrow$ KO: KO mice transplanted with WT bone marrow; KO $\rightarrow$ KO: KO mice transplanted with KO bone marrow.

Immunohistochemical examination of tissue sections through the brain revealed that $\mathrm{GFP}^{+}$cells (originating from the transplanted bone marrow cells) were associated with the brain blood vessels (Fig. 2, A1-A2). GFP ${ }^{+}$cells were also observed in brain parenchyma. These had a different morphology than those seen in blood vessels, and strongly reminded of microglial cells. Several clusters with variable number of microglia-like cells were observed, being predominantly localized to various limbic regions, including the hypothalamus (Fig. 2, A3, Supplementary Fig. 1). In each brain their distribution was quite symmetric, and the patterns across brains were often consistent. To further characterize the blood-brain barrier cells that were immune-positive for GFP, brain sections were stained for vWF and the mannose receptor CD206, identifying macrophages. Dual labeling of GFP and CD206, identified $\mathrm{GFP}^{+}$cells associated with the walls of blood vessels as perivascular macrophages (Fig. 2B) whereas dual labeling of GFP and vWF showed that the two markers labeled distinct cell populations thus confirming that GFP was not present in endothelial cells (Fig. 
2C). Brain sections from four mice, one from each group of hybrid mice that had been treated with saline, were stained for both GFP and CD206 for quantitative analysis. Examination of 10 randomly selected fields from each of the four mice showed that $81.6 \%$ (SEM 4.5) of the CD206 positive cells also expressed GFP and that $86.7 \%$ (SEM 2.8) of the GFP positive cells also expressed CD206. Accordingly, the irradiation and transplantation procedure generated highly selective and extensive replacement of native hematopoietic cells with transplanted cells both in blood and brain.

Fig. 2

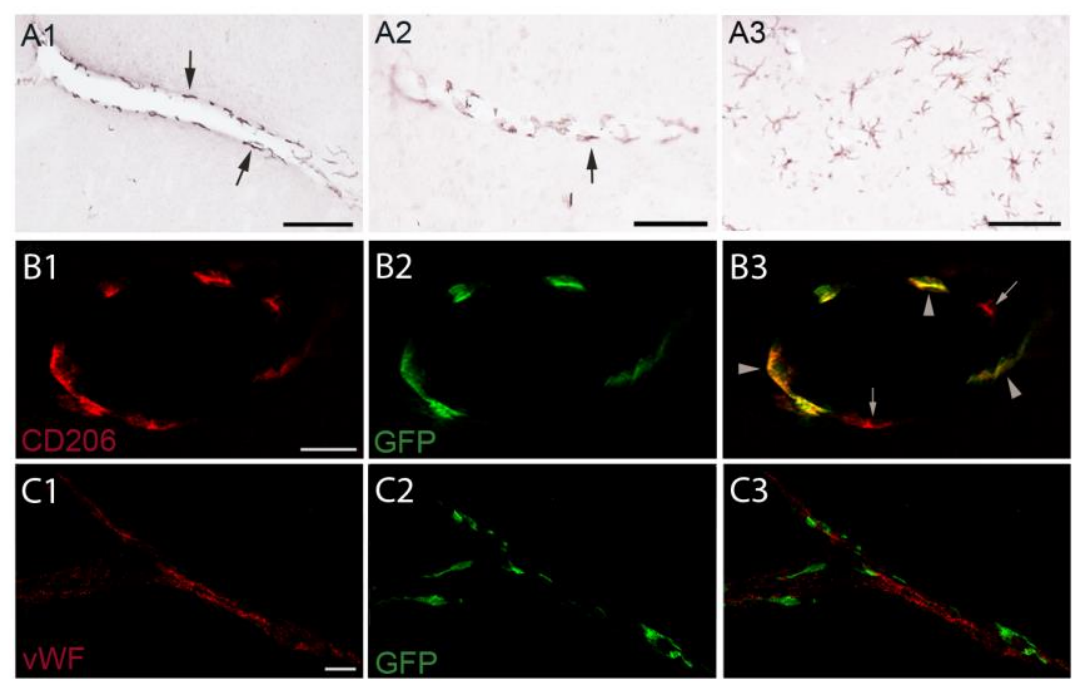

Fig. 2. Reconstitution of hematopoietically derived cells in mouse brain following whole body irradiation and repopulation of the bone marrow by transplantation with CD45 enriched GFP positive cells

Representative illustration from cerebral cortex of a $\mathrm{KO} \rightarrow \mathrm{KO}$ mouse. (A) Light micrographs of GFP positive cells in the brain. A1 and A2 show labeled cells (arrows) associated with blood vessels and A3 a cluster of labeled microglial like cells in the brain parenchyma. (B-C) Confocal images of GFP-positive cells (green) along the brain blood vessels, together with (B) CD206 (red), a marker for perivascular macrophages, and (C) the von Willebrand factor (vWF; red), an endothelial cell marker. Arrowheads in B point at cells that express both GFP and CD206, and arrows denote single-labeled cell that only express CD206 or GFP. There was no co-localization between GFP and vWF expressing cells (C). Scale bar $=50 \mu \mathrm{m}$ in [A], and $25 \mu \mathrm{m}$ in [B and C].

\subsection{LPS induces a febrile response in mice with an intact IL-6 synthesis in cells}

\section{of non-hematopoietic origin}


Five months after irradiation and transplantation, the temperature response of the chimeric mice to i.p. injected LPS (120 $\mu \mathrm{g} / \mathrm{kg}$ b.w) was examined (Fig. 3). In the WT $\rightarrow$ WT group intraperitoneal injection of LPS resulted in a typical triphasic fever with the first phase being obscured by the hyperthermia induced by the handling stress associated with the injection, similar to what has previously been reported in WT mice (Nilsberth et al., 2009a; Nilsberth et al., 2009b; Rudaya et al., 2005). $\mathrm{KO} \rightarrow \mathrm{KO}$ mice displayed no fever, similar to what is seen in mice with global deletion of the IL-6 gene (Chai et al., 1996). KO $\rightarrow$ WT mice (having intact synthesis of IL-6 only in cells of non-hematopoietic origin), displayed a normal febrile response, similar to that observed in the $\mathrm{WT} \rightarrow \mathrm{WT}$ group. In contrast, $\mathrm{WT} \rightarrow \mathrm{KO}$ mice (lacking the expression of IL-6 in all cells but those of hematopoietic lineage), showed a statistically significant elevation of the body temperature only in the time period of $2-3 \frac{1}{2} \mathrm{~h}$ after the LPS injection (Fig. 3). This elevation of body temperature coincided with the second phase of fever but was of much lower magnitude than the corresponding elevation of body temperature observed in $\mathrm{WT} \rightarrow \mathrm{WT}$ mice. Apart from this elevation the temperature response was similar to that of the $\mathrm{KO} \rightarrow \mathrm{KO}$ group. These data hence indicate that IL- 6 expressed by non-hematopoietic cells is critical for the febrile response whereas IL-6 expressed by hematopoietic cells only has minor influence on this response. 
Fig. 3

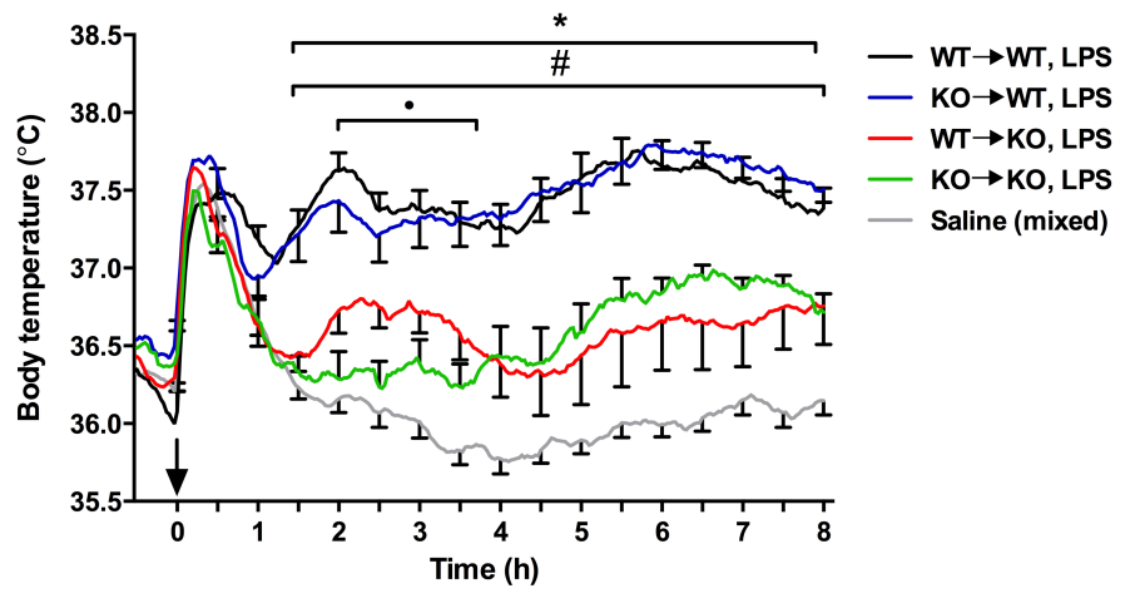

Fig. 3. IL-6 produced by non-hematopoietic cells is critical for the fever response

Chimeric mice were injected intraperitoneally with LPS (120 $\mu \mathrm{g} / \mathrm{kg} \mathrm{b.w})$ at time $0 \mathrm{~h}$ and the body temperature was recorded at thermoneutral conditions (29$30^{\circ} \mathrm{C}$ ). Mice that were injected with saline did not differ in body temperature between the different chimeras, and their average temperature response is therefore given. In the LPS groups, $n=13$ for WT $\rightarrow$ WT mice, $n=15$ for WT $\rightarrow$ KO mice, $n=12$ for $\mathrm{KO} \rightarrow$ WT mice, and $n=8$ for $\mathrm{KO} \rightarrow \mathrm{KO}$ mice. $n=34$ in the pooled saline group $(n=8$ for WT $\rightarrow$ WT mice, $n=10$ for WT $\rightarrow$ KO mice, $n=9$ for KO $\rightarrow$ WT mice, and $n=7$ for KO $\rightarrow$ KO mice). Significance symbols indicates $P<$ 0.05 between treatments in $\mathrm{WT} \rightarrow \mathrm{WT}$ mice $\left({ }^{*}\right), \mathrm{KO} \rightarrow \mathrm{WT}$ mice $(\#)$, and $\mathrm{WT} \rightarrow \mathrm{KO}$ mice $(\bullet)$, respectively. No significant differences were found between treatment for $\mathrm{KO} \rightarrow \mathrm{KO}$ mice. Error bars indicate SEM.

\subsection{IL-6 mRNA induction in cerebral cortex follows the recipient's genotype}

The expression of IL-6 mRNA in the cerebral cortex, determined by real time RT-PCR, was examined in the different chimeras in order to determine whether the observed difference in the febrile response correlated with the expression of IL-6. Control mice were injected with saline only. The analysis, performed $3 \mathrm{~h}$ after LPS injection, revealed that IL- 6 mRNA was strongly induced in $\mathrm{KO} \rightarrow \mathrm{WT}$ and $\mathrm{WT} \rightarrow \mathrm{WT}$ mice resulting in similar expression levels in these genotypes (approximately 6 times higher than in saline-injected mice; $P<0.001$ ) (Fig. 4), whereas there was no induction of IL-6 mRNA in $\mathrm{WT} \rightarrow \mathrm{KO}$ mice and $\mathrm{KO} \rightarrow \mathrm{KO}$ mice, which displayed similar expression levels as saline treated mice (Fig. 4). 


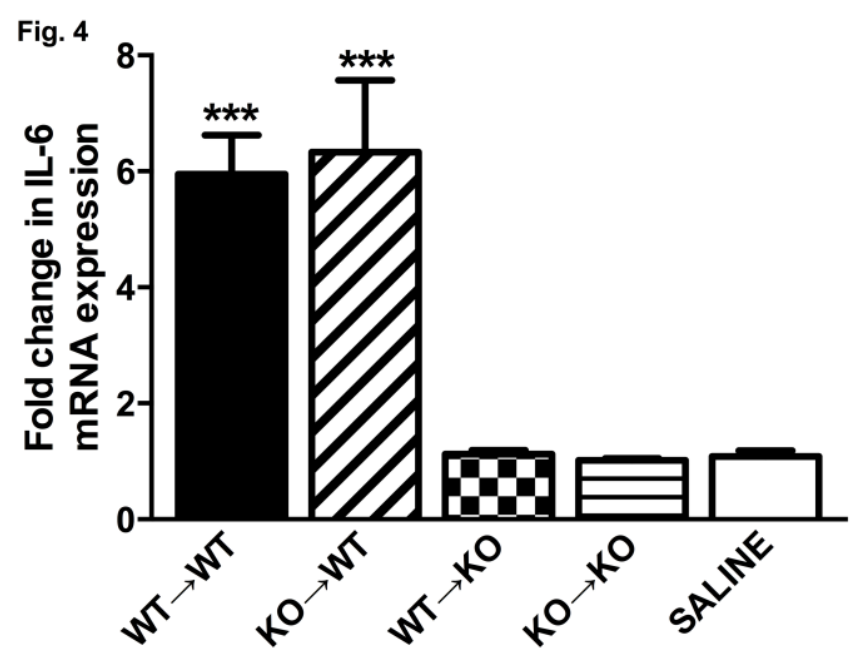

Fig. 4. IL-6 mRNA expression in cerebral cortex

Expression of IL-6 in the cerebral cortex of chimeric mice injected intraperitoneally with LPS (120 $\mu \mathrm{g} / \mathrm{kg}$ b.w) or saline, as determined by qPCR. In the LPS treated groups, $n=8$ for WT $\rightarrow$ WT mice, $n=9$ for $\mathrm{KO} \rightarrow \mathrm{WT}$ mice, $n=12$ for $\mathrm{WT} \rightarrow \mathrm{KO}$ mice, and $n=7$ for KO $\rightarrow \mathrm{KO}$ mice. $\mathrm{n}=10$ in the pooled saline group $(n$ $=2$ for $\mathrm{WT} \rightarrow \mathrm{WT}$ mice, $n=3$ for $\mathrm{KO} \rightarrow \mathrm{WT}$ mice, $n=2$ for $\mathrm{WT} \rightarrow \mathrm{KO}$ mice, and $n=3$ for $\mathrm{KO} \rightarrow \mathrm{KO}$; see also illustration of the separate saline groups in Supplementary Fig. 3). Fold changes are relative to values obtained from the WT $\rightarrow$ WT mice treated with saline. $* * *$ indicates $P<0.001$.

\subsection{IL-6 in plasma and cerebrospinal fluid is strongly induced in mice on WT} background, and only marginally elevated in KO mice transplanted with WT

\section{bone marrow}

The data presented above suggests that IL-6 mRNA in the brain was produced by nonhematopoietic cells. In order to further characterize the role of IL-6 during fever, the levels of IL-6 in plasma and CSF were quantified. We found that IL-6 was strongly induced in both plasma and $\mathrm{CSF}$ of $\mathrm{KO} \rightarrow \mathrm{WT}$ mice $3 \mathrm{~h}$ after peripheral injection of LPS, similar to what was seen in WT $\rightarrow$ WT mice (Fig. 5A and 5B). While IL-6 was significantly elevated in plasma and CSF also in LPS-treated WT $\rightarrow \mathrm{KO}$ mice, this elevation was however much smaller than that seen in the mice on a WT background. IL-6 levels in plasma and CSF in the LPS-treated $\mathrm{KO} \rightarrow \mathrm{KO}$ mice as well as in the saline-treated mice were below detection limit. 
A

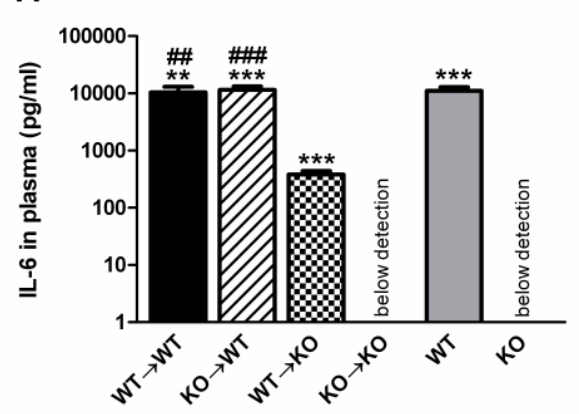

B

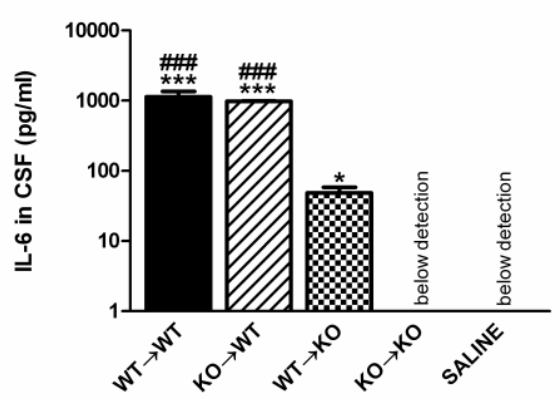

Fig. 5. IL-6 concentration in plasma and cerebrospinal fluid of chimeric mice 3 hours following intraperitoneal injection with LPS (120 $\mu \mathrm{g} / \mathrm{kg}$ b.w)

(A) IL-6 in plasma. Note that the values are illustrated using a logarithmic scale as they were not normally distributed. IL-6 was also measured in plasma of LPStreated non-transplanted WT and IL-6 KO mice, used here as assay controls. $n=5$ for WT $\rightarrow$ WT mice, $n=7$ for KO $\rightarrow$ WT mice, $n=6$ for WT $\rightarrow \mathrm{KO}$ mice, $n=6$ for $\mathrm{KO} \rightarrow \mathrm{KO}$ mice, and $n=7$ for WT mice and KO mice. ** $P<0.01$, ***P $P 0.001$ as compared to the $\mathrm{KO} \rightarrow \mathrm{KO}$ group, and \#\# $P<0.01$, \#\#\# $P<0.001$ as compared to the WT $\rightarrow \mathrm{KO}$ group. (B) IL-6 in cerebrospinal fluid. The values are illustrated using a logarithmic scale. $n=5$ for WT $\rightarrow$ WT mice, $n=4$ for $\mathrm{KO} \rightarrow \mathrm{WT}, n=6$ for $\mathrm{WT} \rightarrow \mathrm{KO}$ mice, and $n=5$ for $\mathrm{KO} \rightarrow \mathrm{KO}$ mice given LPS. $n=12$ in the saline group (pooled from different chimeras: $n=2$ for $\mathrm{WT} \rightarrow \mathrm{WT}$ mice, $n=3$ for $\mathrm{KO} \rightarrow \mathrm{WT}, n=2$ for $\mathrm{WT} \rightarrow \mathrm{KO}$ mice, and $n=5$ for $\mathrm{KO} \rightarrow \mathrm{KO}$ mice) $* * * P<0.001$ as compared to saline control. \#\#\# $P<0.001$ as compared to $\mathrm{WT} \rightarrow \mathrm{KO}$ mice.

\section{Discussion}

A large amount of evidence identifies IL-6 as a necessary factor for the fever response even though IL-6 by itself is not or only weakly or moderately pyrogenic (Cao et al., 2001; Cartmell et al., 2000; Chai et al., 1996; Harden et al., 2008; Kozak et al., 1998; LeMay et al., 1990; Lenczowski et al., 1999; Nilsberth et al., 2009a; Rummel et al., 2006). However, the origin of IL-6 in immune-induced fever has not been fully identified, although there are reports showing that IL-6 can be produced by a variety of cells in response to different pathological stimuli. The present paper aimed to clarify the contribution of hematopoietically and non-hematopoietically derived IL-6 in enabling the febrile response upon peripheral immune challenge with LPS, using chimeric mice that expressed IL-6 either in the cells of hematopoietic or non-hematopoietic origin.

Our results demonstrate that IL-6 synthesized by hematopoietic cells only has minor influence on the febrile response to LPS and that IL-6 derived from cells of non- 
hematopoietic origin is critical for this response. This fits well with the results from a clinical study where bone-marrow transplanted children with peripheral leucopenia following ablation of hematopoeisis developed fever associated with increased levels of circulating IL-6 (Pechumer et al., 1995).

Although the irradiation and transplantation procedure provides the possibility to examine the importance of a particular gene in the hematopoietic system, it has been reported to compromise the immune response in the brain of the recipients and lead to a substantial infiltration of bone-marrow derived microglia (Simard et al., 2006). Moreover, some of the observed effects of microglia entering the brain were suggested to be directly related to the irradiation effects on the blood-brain barrier (Ajami et al., 2007; Lucin and Wyss-Coray, 2009). However, this issue was systematically studied by Turrin et al. (2007) who compared the brain expression of innate immune markers in normal, GFP-expressing, and chimeric mice, respectively, upon LPS administration. They found similar expression of these markers in all three groups of mice and concluded that the innate immune response of chimeric mice is similar to that of WT mice (Turrin et al., 2007). Furthermore, in a previous study (Engstrom et al., 2012) we demonstrated that although the irradiation and transplantation, similar to what was seen in the present study, resulted in a major replacement of brain perivascular cells the fever response of $\mathrm{WT} \rightarrow \mathrm{WT}$ and $\mathrm{KO} \rightarrow \mathrm{KO}$ mice was similar to that of non-irradiated $\mathrm{WT}$ and KO mice, respectively, suggesting that the irradiation procedure per se did not affect the fever response. The same observation was obtained in the present study, and while it does not exclude that the irradiation procedure could have influenced peripheral and central IL-6 levels in the chimeric mice, it seems unlikely that any such changes would have significantly influenced the febrile responses in these mice.

In evaluating the present findings it is also important to consider the neuroendocrineactivated environment in which the hematopoietic cells were immune challenged and to what 
extent this may differ between genotypes. We reported previously that IL-6 KO mice show intact IL-1 $\beta$ and TNF $\alpha$ expression upon LPS stimulation (Nilsberth et al., 2009b). However, the release of stress hormones may differ. Thus, plasma corticosterone levels in mice devoid of IL-6 have been reported to be significantly lower than in wild-type mice (Bethin et al., 2000; van Enckevort et al., 2001), although conflicting data exist (Fattori et al., 1994; Kozak et al., 1998). Hence, it cannot be excluded that a different neuroendocrine environment in the mice on a KO background could have influenced the response of hematopoietic cells and their IL-6 release.

The present results show that mice on a WT background displayed a WT phenotype irrespective of the genotype of the transplanted hematopoietic cells. Thus, WT mice transplanted with IL-6 KO bone marrow displayed an almost indistinguishable fever response compared to that displayed by WT mice transplanted with WT bone marrow. Both groups responded to LPS with a typical triphasic fever with the second and third temperature peak seen at approximately 120 and 300 min after injection (the first phase being obscured by the stress response associated with the handling during the injection (Rudaya et al., 2005)).

KO mice transplanted with WT bone marrow displayed a modest LPS-induced induction of IL-6 protein in plasma and CSF, but there was no increased mRNA expression in brain tissue, and they also display a small, but statistically significant elevation of the body temperature at 2 - $3 \frac{1}{2} \mathrm{~h}$ after LPS injection. These findings suggest that hematopoietically derived IL-6 of peripheral origin may play a role in generating the second phase of LPS induced fever. Previous work has suggested that the LPS recognition molecule Toll like receptor 4 (TLR4) on immune cells plays a critical role at the onset of the initial phase of fever, and that the later phases of fever are dependent in a redundant way on TLR4 on both hematopoietic and non-hematopoietic cells (Steiner et al., 2006). While those finding seem to indicate that signaling molecules, such as cytokines, released from immune cells initiates 
fever, they are in disagreement with the finding that the initiation of the febrile response elicited by intravenously administrated LPS precedes the appearance of IL- 6 and other cytokines in the blood stream (Cartmell et al., 2000; Givalois et al., 1994; Roth et al., 1993). However, it is possible that hematopoietically derived mediators that are not cytokines may be involved. The present data imply that peripheral IL-6 derived from the hematopoietic cells is involved in the second phase of LPS-induced fever, thus being partly in line with the results from a previous study, in which the peripheral production of pyrogenic cytokines by the hematopoietic cells was suggested to correlate with later febrile phases (Chakravarty and Herkenham, 2005).

Although the present study is the first to identify the non-hematopoietic cells as the major contributor of IL-6 in the LPS-induced fever response, the phenotype of these cells remain to be clarified, and may involve a variety of cell types. Examples of peripheral sources are hepatocytes (Panesar et al., 1999; Saad et al., 1995), skin fibroblasts (Helfgott et al., 1987; May et al., 1988) and mesangial cells of the kidney (Rugo et al., 1992). Cells within or associated to the brain that have been shown to produce IL- 6 are brain endothelial cells (Reyes et al., 1999; Verma et al., 2006), astrocytes, microglia, and neurons (Benveniste et al., 1990; Beurel and Jope, 2009; Ringheim et al., 1995; Sawada et al., 1992; Vallieres and Rivest, 1997).

Whether the increased levels of IL-6 in CSF in mice with an intact synthesis of IL-6 in non-hematopoietic cells, which also responded with fever, was derived from the periphery or the brain thus remains to be clarified, as the levels of IL-6 were highly elevated both in plasma and brain in the chimeric mice. It has previously been reported that blood-borne IL-6 was able to alter the brain function by crossing the blood-brain barrier (Banks et al., 1994), which supports the idea that IL-6 in CSF, at least to some portion, may be derived from the periphery. Furthermore, it was suggested that circulating IL-6 was able to increase the 
vascular permeability of blood vessels in the blood-brain barrier (Paul et al., 2003) and to activate signal transducers and activators of transcription (STAT) 1 and 3 (Rummel et al., 2006), which have been described to be implicated in the damage of blood-brain barrier (Chaudhuri et al., 2008). However, with the current experimental approach we were not able to distinguish centrally produced IL-6 from IL-6 in the periphery, an issue that requires further examination. Recent work from this laboratory has suggested that hematopoietic cells and plasma $\mathrm{PGE}_{2}$ are not contributing to the fever signaling. Instead, the endothelial cells in the brain were identified as the main source of $\mathrm{PGE}_{2}$ important for the fever generation (Engstrom et al., 2012). While IL-6 by itself does not elicit $\mathrm{PGE}_{2}$ synthesis, it is possible that the febrile response never-the-less could be dependent on IL-6 signaling via brain endothelial cells, through a yet unidentified mechanism (Nilsberth et al., 2009a). IL-6 acts by binding to either a soluble form of its receptor (sIL-6R) (Novick et al., 1989) or to a membrane bound form (IL-6R) (Yamasaki et al., 1988). In addition, a third component, gp130, is needed for the signal transduction (Hibi et al., 1990; Taga et al., 1989). Binding of IL-6 to its receptors initiates cellular events including activation of Janus Kinase (JAK) and STAT3. Phosphorylation of STAT3 induces a dimer formation that translocates into the nucleus to activate transcription of genes containing STAT3 response elements. Indeed, both memIL-6R and gp130 have been localized to brain blood vessel cells (Vallieres and Rivest, 1997), and it has been shown that i.p. administration of recombinant IL-6 activates STAT3 in blood vessels of the rat brain (Rummel et al., 2005). Experiment with endothelial cell specific deletion of IL-6 could help clarifying the role of these signaling pathways for the febrile response.

In summary, we have shown that IL-6 produced by non-hematopoietic cells is the major source of IL-6 elicited by peripherally administered LPS, and a critical component for LPSinduced fever. IL-6 produced by hematopoietic cells plays a minor role in the systemic IL-6 production, and contributes to the second phase of fever. 


\section{Acknowledgements}

This study was supported by the Swedish Research Council (\#33X-07879, \#68X-20535, \#64X-21463), the Swedish Cancer Foundation (\#4095), the Swedish Brain Foundation, the

Tore Nilsson Foundation, the Åke Wiberg Foundation, Längmanska Kulturfonden, The Lars

Hierta Memorial Foundation, The Magn. Bergvall Foundation, the County Council of

Östergötland, The Harald and Greta Jeansson Foundation, The Royal Swedish Academy of

Sciences, and the Foundation of the National Board of Health and Welfare.

\section{References}

Ajami, B., Bennett, J.L., Krieger, C., Tetzlaff, W., Rossi, F.M., 2007. Local self-renewal can sustain CNS microglia maintenance and function throughout adult life. Nat Neurosci 10, 1538-1543.

Andreasen, A.S., Kelly, M., Berg, R.M., Moller, K., Pedersen, B.K., 2011. Type 2 diabetes is associated with altered NF-kappaB DNA binding activity, JNK phosphorylation, and AMPK phosphorylation in skeletal muscle after LPS. PLoS ONE 6, e23999.

Banks, W.A., Kastin, A.J., Gutierrez, E.G., 1994. Penetration of interleukin-6 across the murine blood-brain barrier. Neurosci Lett 179, 53-56.

Bauer, J., Ganter, U., Geiger, T., Jacobshagen, U., Hirano, T., Matsuda, T., Kishimoto, T., Andus, T., Acs, G., Gerok, W., et al., 1988. Regulation of interleukin-6 expression in cultured human blood monocytes and monocyte-derived macrophages. Blood 72, 11341140 .

Benveniste, E.N., Sparacio, S.M., Norris, J.G., Grenett, H.E., Fuller, G.M., 1990. Induction and regulation of interleukin-6 gene expression in rat astrocytes. J Neuroimmunol 30, 201-212.

Bethin, K.E., Vogt, S.K., Muglia, L.J., 2000. Interleukin-6 is an essential, corticotropinreleasing hormone-independent stimulator of the adrenal axis during immune system activation. Proc Natl Acad Sci U S A 97, 9317-9322.

Beurel, E., Jope, R.S., 2009. Lipopolysaccharide-induced interleukin-6 production is controlled by glycogen synthase kinase-3 and STAT3 in the brain. J Neuroinflammation $6,9$.

Blatteis, C.M., 1990. Neuromodulative actions of cytokines. Yale J Biol Med 63, 133-146.

Callery, M.P., Kamei, T., Flye, M.W., 1992. Endotoxin stimulates interleukin-6 production by human Kupffer cells. Circ Shock 37, 185-188.

Cao, C., Matsumura, K., Shirakawa, N., Maeda, M., Jikihara, I., Kobayashi, S., Watanabe, Y., 2001. Pyrogenic cytokines injected into the rat cerebral ventricle induce cyclooxygenase- 2 in brain endothelial cells and also upregulate their receptors. Eur J Neurosci 13, 1781-1790. 
Cartmell, T., Poole, S., Turnbull, A.V., Rothwell, N.J., Luheshi, G.N., 2000. Circulating interleukin-6 mediates the febrile response to localised inflammation in rats. J Physiol 526 Pt 3, 653-661.

Chai, Z., Gatti, S., Toniatti, C., Poli, V., Bartfai, T., 1996. Interleukin (IL)-6 gene expression in the central nervous system is necessary for fever response to lipopolysaccharide or IL-1 beta: a study on IL-6-deficient mice. J Exp Med 183, 311-316.

Chakravarty, S., Herkenham, M., 2005. Toll-like receptor 4 on nonhematopoietic cells sustains CNS inflammation during endotoxemia, independent of systemic cytokines. J Neurosci 25, 1788-1796.

Chaudhuri, A., Yang, B., Gendelman, H.E., Persidsky, Y., Kanmogne, G.D., 2008. STAT1 signaling modulates HIV-1-induced inflammatory responses and leukocyte transmigration across the blood-brain barrier. Blood 111, 2062-2072.

Conti, B., Tabarean, I., Andrei, C., Bartfai, T., 2004. Cytokines and fever. Front Biosci 9, 1433-1449.

Dinarello, C.A., Cannon, J.G., Mancilla, J., Bishai, I., Lees, J., Coceani, F., 1991. Interleukin6 as an endogenous pyrogen: induction of prostaglandin E2 in brain but not in peripheral blood mononuclear cells. Brain Res 562, 199-206.

Eliasson, P., Rehn, M., Hammar, P., Larsson, P., Sirenko, O., Flippin, L.A., Cammenga, J., Jonsson, J.I., 2010. Hypoxia mediates low cell-cycle activity and increases the proportion of long-term-reconstituting hematopoietic stem cells during in vitro culture. Exp Hematol 38, 301-310 e302.

Engblom, D., Saha, S., Engstrom, L., Westman, M., Audoly, L.P., Jakobsson, P.J., Blomqvist, A., 2003. Microsomal prostaglandin E synthase-1 is the central switch during immuneinduced pyresis. Nat Neurosci 6, 1137-1138.

Engstrom, L., Ruud, J., Eskilsson, A., Larsson, A., Mackerlova, L., Kugelberg, U., Qian, H., Vasilache, A.M., Larsson, P., Engblom, D., Sigvardsson, M., Jonsson, J.I., Blomqvist, A., 2012. Lipopolysaccharide-induced fever depends on prostaglandin E2 production specifically in brain endothelial cells. Endocrinology 153, 4849-4861.

Fattori, E., Cappelletti, M., Costa, P., Sellitto, C., Cantoni, L., Carelli, M., Faggioni, R., Fantuzzi, G., Ghezzi, P., Poli, V., 1994. Defective inflammatory response in interleukin 6-deficient mice. J Exp Med 180, 1243-1250.

Flower, L., Gray, R., Pinkney, J., Mohamed-Ali, V., 2003. Stimulation of interleukin-6 release by interleukin-1beta from isolated human adipocytes. Cytokine 21, 32-37.

Galea, I., Palin, K., Newman, T.A., Van Rooijen, N., Perry, V.H., Boche, D., 2005. Mannose receptor expression specifically reveals perivascular macrophages in normal, injured, and diseased mouse brain. Glia 49, 375-384.

Givalois, L., Dornand, J., Mekaouche, M., Solier, M.D., Bristow, A.F., Ixart, G., Siaud, P., Assenmacher, I., Barbanel, G., 1994. Temporal cascade of plasma level surges in ACTH, corticosterone, and cytokines in endotoxin-challenged rats. Am J Physiol 267, R164-170.

Harden, L.M., du Plessis, I., Poole, S., Laburn, H.P., 2008. Interleukin (IL)-6 and IL-1 beta act synergistically within the brain to induce sickness behavior and fever in rats. Brain Behav Immun 22, 838-849.

Harre, E.M., Roth, J., Pehl, U., Kueth, M., Gerstberger, R., Hubschle, T., 2002. Selected contribution: role of IL-6 in LPS-induced nuclear STAT3 translocation in sensory circumventricular organs during fever in rats. J Appl Physiol 92, 2657-2666.

Helfgott, D.C., May, L.T., Sthoeger, Z., Tamm, I., Sehgal, P.B., 1987. Bacterial lipopolysaccharide (endotoxin) enhances expression and secretion of beta 2 interferon by human fibroblasts. J Exp Med 166, 1300-1309. 
Herrero, L., Shapiro, H., Nayer, A., Lee, J., Shoelson, S.E., 2010. Inflammation and adipose tissue macrophages in lipodystrophic mice. Proc Natl Acad Sci U S A 107, 240-245.

Hibi, M., Murakami, M., Saito, M., Hirano, T., Taga, T., Kishimoto, T., 1990. Molecular cloning and expression of an IL-6 signal transducer, gp130. Cell 63, 1149-1157.

Jaffe, E.A., Hoyer, L.W., Nachman, R.L., 1974. Synthesis of von Willebrand factor by cultured human endothelial cells. Proc Natl Acad Sci U S A 71, 1906-1909.

Kakumu, S., Fukatsu, A., Shinagawa, T., Kurokawa, S., Kusakabe, A., 1992. Localisation of intrahepatic interleukin 6 in patients with acute and chronic liver disease. J Clin Pathol 45, 408-411.

Kluger, M.J., Ringler, D.H., Anver, M.R., 1975. Fever and survival. Science 188, 166-168.

Kozak, W., Kluger, M.J., Soszynski, D., Conn, C.A., Rudolph, K., Leon, L.R., Zheng, H., 1998. IL-6 and IL-1 beta in fever. Studies using cytokine-deficient (knockout) mice. Ann N Y Acad Sci 856, 33-47.

Lazarus, M., Yoshida, K., Coppari, R., Bass, C.E., Mochizuki, T., Lowell, B.B., Saper, C.B., 2007. EP3 prostaglandin receptors in the median preoptic nucleus are critical for fever responses. Nat Neurosci 10, 1131-1133.

LeMay, L.G., Vander, A.J., Kluger, M.J., 1990. Role of interleukin 6 in fever in rats. Am J Physiol 258, R798-803.

Lenczowski, M.J., Bluthe, R.M., Roth, J., Rees, G.S., Rushforth, D.A., van Dam, A.M., Tilders, F.J., Dantzer, R., Rothwell, N.J., Luheshi, G.N., 1999. Central administration of rat IL-6 induces HPA activation and fever but not sickness behavior in rats. Am J Physiol 276, R652-658.

Lucin, K.M., Wyss-Coray, T., 2009. Immune activation in brain aging and neurodegeneration: too much or too little? Neuron 64, 110-122.

May, L.T., Ghrayeb, J., Santhanam, U., Tatter, S.B., Sthoeger, Z., Helfgott, D.C., Chiorazzi, N., Grieninger, G., Sehgal, P.B., 1988. Synthesis and secretion of multiple forms of beta 2-interferon/B-cell differentiation factor 2/hepatocyte-stimulating factor by human fibroblasts and monocytes. J Biol Chem 263, 7760-7766.

Nadjar, A., Tridon, V., May, M.J., Ghosh, S., Dantzer, R., Amedee, T., Parnet, P., 2005. NFkappaB activates in vivo the synthesis of inducible Cox-2 in the brain. J Cereb Blood Flow Metab 25, 1047-1059.

Nilsberth, C., Elander, L., Hamzic, N., Norell, M., Lonn, J., Engstrom, L., Blomqvist, A., 2009a. The role of interleukin-6 in lipopolysaccharide-induced fever by mechanisms independent of prostaglandin E2. Endocrinology 150, 1850-1860.

Nilsberth, C., Hamzic, N., Norell, M., Blomqvist, A., 2009b. Peripheral lipopolysaccharide administration induces cytokine mRNA expression in the viscera and brain of feverrefractory mice lacking microsomal prostaglandin E synthase-1. J Neuroendocrinol 21, 715-721.

Northoff, H., Andus, T., Tran-Thi, T.A., Bauer, J., Decker, K., Kubanek, B., Heinrich, P.C., 1987. The inflammation mediators interleukin 1 and hepatocyte-stimulating factor are differently regulated in human monocytes. Eur J Immunol 17, 707-711.

Novick, D., Engelmann, H., Wallach, D., Rubinstein, M., 1989. Soluble cytokine receptors are present in normal human urine. J Exp Med 170, 1409-1414.

Oka, T., Oka, K., Kobayashi, T., Sugimoto, Y., Ichikawa, A., Ushikubi, F., Narumiya, S., Saper, C.B., 2003. Characteristics of thermoregulatory and febrile responses in mice deficient in prostaglandin EP1 and EP3 receptors. J Physiol 551, 945-954.

Okabe, M., Ikawa, M., Kominami, K., Nakanishi, T., Nishimune, Y., 1997. 'Green mice' as a source of ubiquitous green cells. FEBS Lett 407, 313-319.

Panesar, N., Tolman, K., Mazuski, J.E., 1999. Endotoxin stimulates hepatocyte interleukin-6 production. J Surg Res 85, 251-258. 
Paul, R., Koedel, U., Winkler, F., Kieseier, B.C., Fontana, A., Kopf, M., Hartung, H.P., Pfister, H.W., 2003. Lack of IL-6 augments inflammatory response but decreases vascular permeability in bacterial meningitis. Brain 126, 1873-1882.

Pechumer, H., Wilhelm, M., Ziegler-Heitbrock, H.W., 1995. Interleukin-6 (IL-6) levels in febrile children during maximal aplasia after bone marrow transplantation (BMT) are similar to those in children with normal hematopoiesis. Ann Hematol 70, 309-312.

Reyes, T.M., Fabry, Z., Coe, C.L., 1999. Brain endothelial cell production of a neuroprotective cytokine, interleukin-6, in response to noxious stimuli. Brain Res 851, 215-220.

Ringheim, G.E., Burgher, K.L., Heroux, J.A., 1995. Interleukin-6 mRNA expression by cortical neurons in culture: evidence for neuronal sources of interleukin-6 production in the brain. J Neuroimmunol 63, 113-123.

Roedder, S., Kimura, N., Okamura, H., Hsieh, S.C., Gong, Y., Sarwal, M.M., 2013. Significance and suppression of redundant IL17 responses in acute allograft rejection by bioinformatics based drug repositioning of fenofibrate. PLoS ONE 8, e56657.

Romanovsky, A.A., Kulchitsky, V.A., Simons, C.T., Sugimoto, N., 1998. Methodology of fever research: why are polyphasic fevers often thought to be biphasic? Am J Physiol 275, R332-338.

Roth, J., Conn, C.A., Kluger, M.J., Zeisberger, E., 1993. Kinetics of systemic and intrahypothalamic IL-6 and tumor necrosis factor during endotoxin fever in guinea pigs. Am J Physiol 265, R653-658.

Rudaya, A.Y., Steiner, A.A., Robbins, J.R., Dragic, A.S., Romanovsky, A.A., 2005. Thermoregulatory responses to lipopolysaccharide in the mouse: dependence on the dose and ambient temperature. Am J Physiol Regul Integr Comp Physiol 289, R12441252.

Rugo, H.S., O'Hanley, P., Bishop, A.G., Pearce, M.K., Abrams, J.S., Howard, M., O'Garra, A., 1992. Local cytokine production in a murine model of Escherichia coli pyelonephritis. J Clin Invest 89, 1032-1039.

Rummel, C., Hubschle, T., Gerstberger, R., Roth, J., 2004. Nuclear translocation of the transcription factor STAT3 in the guinea pig brain during systemic or localized inflammation. J Physiol 557, 671-687.

Rummel, C., Matsumura, K., Luheshi, G.N., 2011. Circulating IL-6 contributes to peripheral LPS-induced mPGES-1 expression in the rat brain. Brain Res Bull 86, 319-325.

Rummel, C., Sachot, C., Poole, S., Luheshi, G.N., 2006. Circulating interleukin-6 induces fever through a STAT3-linked activation of COX-2 in the brain. Am J Physiol Regul Integr Comp Physiol 291, R1316-1326.

Rummel, C., Voss, T., Matsumura, K., Korte, S., Gerstberger, R., Roth, J., Hubschle, T., 2005. Nuclear STAT3 translocation in guinea pig and rat brain endothelium during systemic challenge with lipopolysaccharide and interleukin-6. J Comp Neurol 491, 114.

Saad, B., Frei, K., Scholl, F.A., Fontana, A., Maier, P., 1995. Hepatocyte-derived interleukin6 and tumor-necrosis factor alpha mediate the lipopolysaccharide-induced acute-phase response and nitric oxide release by cultured rat hepatocytes. Eur J Biochem 229, 349355.

Sakata, Y., Morimoto, A., Long, N.C., Murakami, N., 1991. Fever and acute-phase response induced in rabbits by intravenous and intracerebroventricular injection of interleukin-6. Cytokine 3, 199-203.

Sawada, M., Suzumura, A., Marunouchi, T., 1992. TNF alpha induces IL-6 production by astrocytes but not by microglia. Brain Res 583, 296-299. 
Semple, B.D., Frugier, T., Morganti-Kossmann, M.C., 2010. CCL2 modulates cytokine production in cultured mouse astrocytes. J Neuroinflammation 7, 67.

Simard, A.R., Soulet, D., Gowing, G., Julien, J.P., Rivest, S., 2006. Bone marrow-derived microglia play a critical role in restricting senile plaque formation in Alzheimer's disease. Neuron 49, 489-502.

Sporn, L.A., Marder, V.J., Wagner, D.D., 1986. Inducible secretion of large, biologically potent von Willebrand factor multimers. Cell 46, 185-190.

Steiner, A.A., Chakravarty, S., Rudaya, A.Y., Herkenham, M., Romanovsky, A.A., 2006. Bacterial lipopolysaccharide fever is initiated via Toll-like receptor 4 on hematopoietic cells. Blood 107, 4000-4002.

Taga, T., Hibi, M., Hirata, Y., Yamasaki, K., Yasukawa, K., Matsuda, T., Hirano, T., Kishimoto, T., 1989. Interleukin-6 triggers the association of its receptor with a possible signal transducer, gp130. Cell 58, 573-581.

Turrin, N.P., Plante, M.M., Lessard, M., Rivest, S., 2007. Irradiation does not compromise or exacerbate the innate immune response in the brains of mice that were transplanted with bone marrow stem cells. Stem Cells 25, 3165-3172.

Vallieres, L., Rivest, S., 1997. Regulation of the genes encoding interleukin-6, its receptor, and gp130 in the rat brain in response to the immune activator lipopolysaccharide and the proinflammatory cytokine interleukin-1beta. J Neurochem 69, 1668-1683.

van Enckevort, F.H., Sweep, C.G., Span, P.N., Demacker, P.N., Hermsen, C.C., Hermus, A.R., 2001. Reduced adrenal response to bacterial lipopolysaccharide in interleukin-6deficient mice. J Endocrinol Invest 24, 786-795.

Wang, J., Ando, T., Dunn, A.J., 1997. Effect of homologous interleukin-1, interleukin-6 and tumor necrosis factor-alpha on the core body temperature of mice.

Neuroimmunomodulation 4, 230-236.

Verma, S., Nakaoke, R., Dohgu, S., Banks, W.A., 2006. Release of cytokines by brain endothelial cells: A polarized response to lipopolysaccharide. Brain Behav Immun 20, 449-455.

Woodroofe, M.N., Sarna, G.S., Wadhwa, M., Hayes, G.M., Loughlin, A.J., Tinker, A., Cuzner, M.L., 1991. Detection of interleukin-1 and interleukin-6 in adult rat brain, following mechanical injury, by in vivo microdialysis: evidence of a role for microglia in cytokine production. J Neuroimmunol 33, 227-236.

Yamasaki, K., Taga, T., Hirata, Y., Yawata, H., Kawanishi, Y., Seed, B., Taniguchi, T., Hirano, T., Kishimoto, T., 1988. Cloning and expression of the human interleukin-6 (BSF-2/IFN beta 2) receptor. Science 241, 825-828. 


\section{Figure Legends}

Fig. 1. GFP+ cell reconstitution in peripheral blood following irradiation and bone marrow transplantation

Mice with deletion of IL-6 (IL-6 KO) and their wild-type (WT) counterparts were exposed to whole body irradiation destroying the bone marrow stem cells and subsequently repopulated with CD45 enriched bone marrow cells $\left(2 \times 10^{6}\right.$ in a volume of $200 \mu \mathrm{L}$ per mouse) from donor mice (either $\mathrm{GFP}^{+} \mathrm{WT}$ or $\mathrm{GFP}^{+} \mathrm{KO}$ mice) via an intravenous tail injection. The reconstitution of $\mathrm{GFP}^{+}$cells in peripheral blood of recipient mice was analyzed by flow cytometry five months after transplantation. Percentages of GFP labeled white blood cells in recipient mice are shown. WT $\rightarrow$ WT: WT mice transplanted with WT bone marrow; KO $\rightarrow$ WT: WT mice transplanted with $\mathrm{KO}$ bone marrow; $\mathrm{WT} \rightarrow \mathrm{KO}: \mathrm{KO}$ mice transplanted with WT bone marrow; $\mathrm{KO} \rightarrow \mathrm{KO}: \mathrm{KO}$ mice transplanted with $\mathrm{KO}$ bone marrow.

Fig. 2. Reconstitution of hematopoietically derived cells in mouse brain following whole body irradiation and repopulation of the bone marrow by transplantation with CD45 enriched GFP positive cells

Representative illustration from cerebral cortex of a $\mathrm{KO} \rightarrow \mathrm{KO}$ mouse. (A) Light micrographs of GFP positive cells in the brain. A1 and A2 show labeled cells (arrows) associated with blood vessels and A3 a cluster of labeled microglial like cells in the brain parenchyma. (B-C) Confocal images of GFP-positive cells (green) along the brain blood vessels, together with (B) CD206 (red), a marker for perivascular macrophages, and (C) the von Willebrand factor (vWF; red), an endothelial cell marker. Arrowheads in B point at cells that express both GFP and CD206, and arrows denote single-labeled cell that only express CD206 or GFP. There was no co-localization between GFP and vWF expressing cells (C). Scale bar $=50 \mu \mathrm{m}$ in $[\mathrm{A}]$, and $25 \mu \mathrm{m}$ in [B and $\mathrm{C}]$. 


\section{Fig. 3. IL-6 produced by non-hematopoietic cells is critical for the fever response}

Chimeric mice were injected intraperitoneally with LPS $(120 \mu \mathrm{g} / \mathrm{kg}$ b.w $)$ at time $0 \mathrm{~h}$ and the body temperature was recorded at thermoneutral conditions $\left(29-30^{\circ} \mathrm{C}\right)$. Mice that were injected with saline did not differ in body temperature between the different chimeras, and their average temperature response is therefore given. In the LPS groups, $n=13$ for $\mathrm{WT} \rightarrow \mathrm{WT}$ mice, $n=15$ for $\mathrm{WT} \rightarrow \mathrm{KO}$ mice, $n=12$ for $\mathrm{KO} \rightarrow \mathrm{WT}$ mice, and $n=8$ for $\mathrm{KO} \rightarrow \mathrm{KO}$ mice. $n=34$ in the pooled saline group $(n=8$ for WT $\rightarrow$ WT mice, $n=10$ for $\mathrm{WT} \rightarrow \mathrm{KO}$ mice, $n=9$ for $\mathrm{KO} \rightarrow \mathrm{WT}$ mice, and $n=7$ for $\mathrm{KO} \rightarrow \mathrm{KO}$ mice). Significance symbols indicates $P<0.05$ between treatments in $\mathrm{WT} \rightarrow \mathrm{WT}$ mice $(*), \mathrm{KO} \rightarrow \mathrm{WT}$ mice (\#), and $\mathrm{WT} \rightarrow \mathrm{KO}$ mice $(\bullet)$, respectively. No significant differences were found between treatment for $\mathrm{KO} \rightarrow \mathrm{KO}$ mice. Error bars indicate SEM.

\section{Fig. 4. IL-6 mRNA expression in cerebral cortex}

Expression of IL-6 in the cerebral cortex of chimeric mice injected intraperitoneally with LPS $(120 \mu \mathrm{g} / \mathrm{kg}$ b.w) or saline, as determined by qPCR. In the LPS treated groups, $n=8$ for $\mathrm{WT} \rightarrow$ WT mice, $n=9$ for $\mathrm{KO} \rightarrow \mathrm{WT}$ mice, $n=12$ for $\mathrm{WT} \rightarrow \mathrm{KO}$ mice, and $n=7$ for $\mathrm{KO} \rightarrow \mathrm{KO}$ mice. $\mathrm{n}=10$ in the pooled saline group $(n=2$ for $\mathrm{WT} \rightarrow \mathrm{WT}$ mice, $n=3$ for $\mathrm{KO} \rightarrow \mathrm{WT}$ mice, $n$ $=2$ for $\mathrm{WT} \rightarrow \mathrm{KO}$ mice, and $n=3$ for $\mathrm{KO} \rightarrow \mathrm{KO}$; see also illustration of the separate saline groups in Supplementary Fig. 3). Fold changes are relative to values obtained from the $\mathrm{WT} \rightarrow \mathrm{WT}$ mice treated with saline. *** indicates $P<0.001$. 
Fig. 5. IL-6 concentration in plasma and cerebrospinal fluid of chimeric mice 3 hours following intraperitoneal injection with $\operatorname{LPS}(120 \mu \mathrm{g} / \mathrm{kg} \mathrm{b.w})$

(A) IL-6 in plasma. Note that the values are illustrated using a logarithmic scale as they were not normally distributed. IL-6 was also measured in plasma of LPS-treated non-transplanted WT and IL-6 KO mice, used here as assay controls. $n=5$ for WT $\rightarrow$ WT mice, $n=7$ for $\mathrm{KO} \rightarrow \mathrm{WT}$ mice, $n=6$ for $\mathrm{WT} \rightarrow \mathrm{KO}$ mice, $n=6$ for $\mathrm{KO} \rightarrow \mathrm{KO}$ mice, and $n=7$ for WT mice and KO mice. ${ }^{* *} P<0.01$, ${ }^{* * *} P<0.001$ as compared to the $\mathrm{KO} \rightarrow \mathrm{KO}$ group, and \#\# $P<0.01$, $\# \# \# P<0.001$ as compared to the $\mathrm{WT} \rightarrow \mathrm{KO}$ group. (B) IL-6 in cerebrospinal fluid. The values are illustrated using a logarithmic scale. $n=5$ for $\mathrm{WT} \rightarrow \mathrm{WT}$ mice, $n=4$ for $\mathrm{KO} \rightarrow \mathrm{WT}$, $n=6$ for $\mathrm{WT} \rightarrow \mathrm{KO}$ mice, and $n=5$ for $\mathrm{KO} \rightarrow \mathrm{KO}$ mice given LPS. $n=12$ in the saline group (pooled from different chimeras: $n=2$ for $\mathrm{WT} \rightarrow \mathrm{WT}$ mice, $n=3$ for $\mathrm{KO} \rightarrow \mathrm{WT}, n=2$ for $\mathrm{WT} \rightarrow \mathrm{KO}$ mice, and $n=5$ for $\mathrm{KO} \rightarrow \mathrm{KO}$ mice) $* * * P<0.001$ as compared to saline control. $\# \# \# P<0.001$ as compared to $\mathrm{WT} \rightarrow \mathrm{KO}$ mice. 